\title{
INFLUENCE KNOWLEDGE LEVEL FUNDAMENTAL ANALYSIS AND TECHNICAL ANALYSIS ON CONTINUITY OF INVESTING IN SHARIA STOCKS IN SHARIA INVESTMENT GALLERY INDONESIA STOCK EXCHANGE STATE INSTITUTE OF ISLAMIC RELIGION KERINCI
}

\author{
Abi Suar ${ }^{1}$, Meirison ${ }^{2}$ \\ UIN Imam Bonjol Padang \\ $\underline{\text { abisuar0505@gmail.com }}^{1}, \underline{\text { meirison@uinib.ac.id }}^{2}$
}

\begin{abstract}
Once the prospection of sharia trading in the capital market must be supported with a level of knowledge in analyzing the stocks that will be traded. Therefore there is an in-depth knowledge of the analysis of sharia stocks before making transactions on the sharia capital market and needed a deepening of understanding on fundamental and technical analysis to achieve optimal profit in the purchase or sale of sharia stocks. This research aims to determine the influence of the knowledge level of fundamental analysis in the continuity of investing in sharia stocks. Influence the level of technical analysis in the continuation of continuity to invest in sharia stocks and the effect of the knowledge level of fundamental and technical analysis simultaneously on the continuity of investing in sharia stocks. The research method used in this research is to use a quantitative approach. The result of the study was on a partial (independent) fundamental analysis level (X1) test for the variable continuity of investing (Y). The influence of knowledge level technical analysis (X2) partially against the Continuity of investing $(Y)$, both get the result of a tcount $<$ Ttable, OR a significant > 0.05. Zero hypotheses (HO) received, and an alternate hypothesis (HA) is rejected, which means variable $X$ does Not affect the variable $Y$. Similar results are also obtained from simultaneous calculations (together).
\end{abstract}

Keywords: investments, sharia stocks, fundamental Analysis, technical analysis.

In the World Era, global investment becomes a necessity in the community to develop the economy, and investments include activities that are highly recommended in Islam. Although in some classical Islamic literature is not found the existence of investment terminology and other terms such as capital markets, stock investments, bonds, and others. But the need for Muslims to invest based on sharia principles is indispensable to minimize investment in conventional institutions (2014). 
Essentially the goal in investing is to gain profit in the future. Therefore, there needs to be careful planning to obtain maximum results and Continuity, in this case, Allah Almighty. Explain in the Qur'an, Surah Al-Hasyr verse 18:

O Those who believe, fear Allah, and have to pay attention to what he has done for tomorrow, and fear Allah, indeed, Allah knows what you are doing. (Tashih al-Qur'an, 2006)

From the above verses, it is clear that if seen from the economic view, there is an order to invest sustainably (continuity) so that the property can develop later by investing and managing it well. Investing in a Shariah perspective is an active form of sharia economics. Investors know the price; the price is the selling or buying value of something traded. The difference in the buying price to the selling price is called profit margin, and the price is formed after the market mechanism. The profit obtained is a means for the improvement of the assets and welfare of the people both at this time and in the future (long term), in this case, Allah SWT has asserted in Al-Quran surah An-Nisa' verse 9: (Tashih al-Qur'an, 2006).

And be afraid of the god of the people who were to leave behind them the weak children, whom they feared for their welfare. Therefore let them fear Allah and let them speak the right words. (Tashih al-Qur'an, 2006)

The passage tells us not to leave Dzurriat Dhi'afa (weak descendants) both in Moryl and Material Allah SWT. Advise people to always pay attention to good economic welfare by always striving and laughing; one of the commercial instruments that can be done by human beings is to develop the property through Sharia investment.

Investing is something that aims to develop the property in possession. Often people are stuck with the notion that investments are related to complex figures. Investments contain the following: specific objectives and needs, the measured amount of funds required, clear timed, alternative investment instruments, and strategies to achieve that goal.

From these things, it takes an appropriate analysis to maximize the investment done, especially the investment done in the Sharia capital market, 
because the capital market is one of the means of investing very effectively and highly favored investors. And the capital market is a means for them to invest in financial instruments such as stocks, mutual, and others. (M. Nur Rianto Al Arif, 2012, p. 21)

Capital market is a market prepared to trade stocks, bonds, and other types of securities by using the services of broker-dealers (Abdul Aziz, 2008, p. 114). While the Sharia capital market (Islamic Stock Exchange) is an activity related to the Sharia securities trading of public companies relating to the published securities and professional institutions related to it, where all the products and operational mechanisms do not contradict Islamic Shari'a. Sharia capital markets can also be interpreted as capital markets that apply Sharia principles (Abdul Hamid, 2008, p. 123).

Sharia stocks are securities that present the inclusion of capital into a company that does not violate Sharia principles. The addition of wealth in the company that does not violate the Sharia principles will reduce losses in investing because the sharia principle prohibits the existence of Gharar, Maysir, Riba, and other things that are haraam syar' $i$.

Once the prospection of sharia trading in the capital market must be supported with a level of knowledge in analyzing the stocks that will be traded. Therefore there is a thorough knowledge of the analysis on the stock before making transactions on the sharia capital market and needed a deepening of understanding on fundamental and technical analysis to achieve maximum profit in the purchase or sale of shares.

In addition to choosing stocks to buy, prospective investors should pay attention to when to purchase shares and when to sell stocks. Because the essence of stock trading is to determine the entry and the time of the sale (Exit). This complements the well-known investment jargon since long ago, "buy at the lowest price and sell it at the highest price." (Naning General, 2001:7)

In the purchase of stocks, it is worth the investor first to analyze the target company. It is necessary to remember the "motto" in Investing in stocks is "high risk, high return." The analysis results of the investor will certainly be very 
influential in the decision making and the Continuity of the transaction on the stock.(Melvilius Welby Cardinal, 2015, p. 2)

From here, it takes a knowledge of fundamental analysis and techniques in Sharia stocks, and broadly, the analytical tools can be grouped into two large groups. First, Fundamental analysis is a method of study based on the company's economic fundamentals. Then the other technical analysis is an analysis of price movements or observations of price movements occurring seconds by second, day by day, within a specified period displayed in the form of charts/graphs. (2014, p. 21)

Fundamental analysis is an analysis that learns things related to the financial condition of a company. This analysis aims to determine the basic properties and operational characteristics of public companies and also to ensure that the stocks purchased are the company's well-performing stocks. So the company has positive expectations towards its share price growth. Fundamental analysis minimizes the risk of likely buying potentially removed stocks from the exchange board.

Knowing the fundamentals of a company will significantly help investors to avoid buying poorly performing stocks. But it can not be used to see when the stock will move up or down. For the sake of simplicity, the poorly performing stocks are the shares of a company that cannot generate profit or loss continuously. Such conditions will undoubtedly affect the movement of its share price. Usually, the cost of the stock will continue to go down, and the trading activity tends to be quiet. Stock prices may not move in a very long period because investors abandon them. (Prabhata, 2012, p. 48)

The technical analysis is a piece of information that will give an overview to the investor to determine when the purchase of stocks is made and when the stock is sold or exchanged with other stocks to make maximum profit. Technical analysis is an analysis of historical data on stock prices. Through historical data owned, it is expected to predict the direction of the next stock movement. This approach uses published market data such as stock price, sales volume, aggregate share price index, and individual, as well as other technical factors. 
Investor Conditions Gallery of Sharia Investment Institute of Islamic Religious Affairs of Kerinci which has differences in the knowledge level of Sharia stock analysis especially in Fundamental and technical analysis resulted in the accumulation of transactions in the last few months has not experienced a significant increase, recorded in September 2018 amounting to Rp 43.429.610, 00 with total customers 302 investors while in October amounted to Rp 90304 49.266.240 The Volume of transactions is contributed from 5\% of investors, meaning there are still 95\% of investors who do not transact. (Astutik, Surachman, \& Djazuli, 2015) This shows that there is still a difference in the level of knowledge in analyzing stocks, especially on fundamental and technical analysis of stocks that make investors not transact continuously. Because one of the reasons for the Continuity of investing in sharia stocks is a good understanding of the investment analysis itself, in other words, a better understanding of investors about fundamental and technical analysis in sharia stocks will become more active as investors invest.

Based on the background of the problem, the author is interested in researching with the title, "Influence of Knowledge level Fundamental analysis and technical to the Continuity of investing in sharia stocks in the Sharia investment gallery of Indonesia Stock Exchange IAIN Kerinci.

\section{METHOD}

This research uses a quantitative approach. This quantitative approach is used to test a theory, to present a fact or describe statistics, to demonstrate relationships between variables, or to develop concepts and understandings. (Subana, 2005, p. 25) This approach is used to calculate the influence of knowledge level of fundamental and technical analysis of continuity of investing in sharia stocks (case study in sharia investment gallery of Indonesian Stock Exchange IAIN Kerinci).

It consists of dependent variable, i.e. continuity of investing in Sharia (Y) shares and independent variables, i.e., fundamental analysis $\left(\mathrm{x}_{1}\right)$ and technical $\left(\mathrm{x}_{2}\right)$, are levels of knowledge. 
Meanwhile, the population and samples, the community is the whole of the observation object and object being a research/generalization area consisting of objects/subjects that have specific qualities and characteristics that the researchers set to learn and then withdraw in its conclusion. The population in this study is all investors of the Sharia investment gallery Indonesia Stock Exchange IAIN Kerinci, several 309 investors, in February 2019.

Samples are part of a population that is considered to represent a population or a research object. (H. Zainuddin Ali, 2004, p. 98) Researchers can study examples taken from the community and then make conclusions to be generalized against the community. For that, samples taken from the city should be truly representative.

The types of data used in this research are: primary data is data that is obtained or collected directly in the field by a person conducting research or that requires. (Fitri \& Matrodji, 2018, p. 21) The primary Data in this study was taken from a poll (post test).

Secondary data is data obtained or collected by people researching existing sources. The sources of data obtained in conducting this research are: investor of Syariah investment Gallery BEI IAIN Kerinci to acquire knowledge level test data of fundamental and technical analysis.

Investment gallery of IDX IAIN Kerinci to obtain the investor's amount and the accumulation of purchase or stock sale transactions made in a certain period.

The data collection in this study was used to test the hypothesis or to answer the questions that have been formulated. The data collection technique in this research is using the primary data of a poll or questionnaire

A questionnaire is a data collection technique done by providing a set of questions or written statements to the respondent to be answered. Poll or Questionnaire technique is an information-gathering tool by presenting several written questions to be answered in writing also by the respondent. (Suharsimi Arikunto, 2002, p. 229) (The poll used in this research is a type of closed poll, so that respondents only choose the answer option that has been provided. 
The research instrument is a benchmark used in conducting a study and is used to measure the value of the variables studied. So, the number of devices used depends on the number of variables in a study. In this study, there are two variables in the research instrument, the level of knowledge of fundamental and technical analysis, and the continuity of investing in sharia stocks.

The validity test is used before researching to measure the legitimate or absence of a measuring device, in this case, the questionnaire. A questionnaire is said to be valid if the question or statement in the survey reveals something that the census will measure. The validity test is done by calculating the correlation between the total score. If the coefficient of the correlate is positive and higher than the $\mathrm{R}$ table, the corresponding indicator is considered valid (the validity of the criteria). The validity test uses Ms. Excel and SPSS 15.0 for Windows program.

Reliability tests show the extent to which a measuring instrument is reliable or trustworthy to measure an object to be measured and to see the consistency of the measuring device in measuring the same symptom. The larger the $\alpha$ (alpha) value, the higher the reliability.

In the data analysis techniques used, classic assumption testing is needed to know whether the estimated regression that is performed is entirely free from the presence of symptoms of heteroskedasticity, multicollinearity symptoms, and average distribution data.

The normality test serves to test the regression model used in the study, and the bully variable has a normal data distribution. This test is used to measure data that is an ordinal scale, interval, or ratio. If analyzed using the parametric method, the requirement of normality must be fulfilled data derived from the normal distribution. If the data is not a normal distribution or too little sample count, it will be used non-parametric statistics. This research will use the OneSample Kolmogorov-Smirnov test using a significance of 0.05. Standard Data, when importance is more significant than 0.05 .

Multicollinearity Test 
Multicollinearity means that there is a perfect or definite linear relationship between some or all of the explanatory variables (free) of the regression model. Further multicollinearity is used in the broad sense of direct correlation between the explanatory variables. (Kurniawan Albert, 2014, p. 65) The Multicolynamic test was also aimed at avoiding the customary conclusions on the influence of partial tests of individual variables independent of the dependent variables.

One of the linear regression that must be met is the homogeneity of the error variable (homoscedasticity). Homoskedastisity means that the variables of the error are constant (fixed) or also called identical. The opposite is the case of heteroscedasticity, i.e., the condition of the error variance (or y) is not similar.

Heteroskedasticity is assuming a spread situation that is not a variant so that a significant test is invalid. The Heteroskedastisity test aims to determine if the regression model used has a variant inequality from the residual of another observation. In the event of Heteroskedastisity, the assessment remains biased and consistent, but the evaluation is no longer efficient in both small and large samples.

Simple linear regression analysis is used to answer the first and second hypotheses and to figure out the partial effect between the free variables $(\mathrm{X})$ of the bound (Ahmad Yusron, 2012, p. 225) variable (Y) using the T. Simple analysis equation is as follows: $\mathrm{Y}=\alpha+\beta \mathrm{x}$ criterion of acceptance and rejection of hypotheses if:

$\mathrm{T}_{\text {calculate }}>\mathrm{t}_{\text {table, }}$, or significant $\leq 0.05$, then the Zero hypothesis (H0) is rejected, and an alternate hypothesis $(\mathrm{Ha})$ is received.

$\mathrm{T}_{\text {count }} \leq \mathrm{t}_{\text {table }}$, or significant $>0.05$, then the Zero hypothesis $(\mathrm{H} 0)$ is received and the alternative hypothesis (HA) is rejected.

Where:

$\alpha=$ Constants

$\beta=$ regression coefficient

2. multiple Linear Regression analysis 
Double linear regression analysis is used to answer the third hypothesis of knowing the simultaneous effect between the free variables (X1 and X1) with a bound variable (Y) using the F. Equation of double linear regression analysis is as follows:

$$
\mathrm{Y}=\alpha+\beta 1 \mathrm{X} 1+\beta 2 \mathrm{X} 2
$$

Criteria for acceptance and rejection of hypotheses if: the value $\mathrm{F}_{\text {counts }}>$

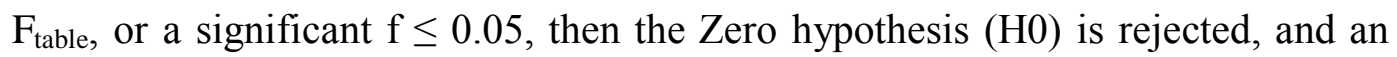
alternate suggestion (Ha) is received.

The value $F_{\text {counts }}<f_{\text {table, }}$ or significantly $\mathrm{f}>0.05$, then the Zero hypothesis (H0) is received, and an alternate hypothesis (Ha) is rejected.

Coefficient of determination, to know the magnitude of variable $\mathrm{X}$ effect to the variable $\mathrm{Y}$, it is calculated coefficient of determination using the equation:

$\mathrm{KD}=\mathrm{R}^{2} \times 100 \%$

Where:

$\mathrm{KD}=$ Coefficient of determination

$\mathrm{R}=\mathrm{PPM}$ Correlation coefficient

\section{RESULTS AND DISCUSSION}

The validity test is used to measure the validity or absence of a questionnaire. The validity test is done by comparing the $\mathrm{R}_{\text {count }}$ value with $\mathrm{R}_{\text {table. If }}$ $\mathrm{R}_{\text {counts }}>\mathrm{R}_{\text {table }}$ with a significant value of 5\% (see Appendix 5), then the measuring instrument used is declared valid and vice versa; if $\mathrm{R}_{\text {counts }}<\mathrm{R}_{\text {table, then the }}$ measuring instrument used is invalid. The validity test is implemented with bivariate person correlation formula with the SPSS program tool version 15.0. In the first validity test, the researcher used ten questions in each Variable with the sample $(\mathrm{N})$ as much as 30 respondents with a summary output of SPSS version 15.0. as follows:

Table 1 Validity test.

\begin{tabular}{|c|c|c|l|l|l|l|l|l|l|}
\hline \multirow{2}{*}{$\begin{array}{c}\text { No. } \\
\mathrm{P}\end{array}$} & \multicolumn{2}{|c|}{ X1 (Fundamental) } & \multicolumn{3}{c|}{ X2 (technical) } & \multicolumn{2}{c|}{$\mathrm{Y}$ (Continuity) } \\
\cline { 2 - 8 } & $\mathrm{R}_{\text {Count }}$ & $\mathrm{R}_{\text {Table }}$ & Ket & $\mathrm{R}_{\text {Count }}$ & $\mathrm{R}_{\text {Table }}$ & Ket & $\mathrm{R}_{\text {Count }}$ & $\mathrm{R}_{\text {Table }}$ & Ket \\
\hline
\end{tabular}




\begin{tabular}{|l|c|c|c|c|c|c|c|c|c|}
\hline 1 & 0.724 & 0.361 & Valid & 0.285 & 0.361 & $\mathrm{X}$ & 0.240 & 0.361 & $\mathrm{X}$ \\
\hline 2 & 0.654 & 0.361 & Valid & 0.724 & 0.361 & Valid & 0.485 & 0.361 & Valid \\
\hline 3 & 0.141 & 0.361 & $\mathrm{X}$ & 0.183 & 0.361 & $\mathrm{X}$ & 0.650 & 0.361 & Valid \\
\hline 4 & 0.671 & 0.361 & Valid & 0.542 & 0.361 & Valid & 0.683 & 0.361 & Valid \\
\hline 5 & 0.316 & 0.361 & $\mathrm{X}$ & 0.318 & 0.361 & Valid & 0.223 & 0.361 & $\mathrm{X}$ \\
\hline 6 & 0.577 & 0.361 & Valid & 0.648 & 0.361 & Valid & 0.671 & 0.361 & Valid \\
\hline 7 & 0.654 & 0.361 & Valid & 0.724 & 0.361 & Valid & 0.183 & 0.361 & $\mathrm{X}$ \\
\hline 8 & 0.167 & 0.361 & $\mathrm{X}$ & 0.519 & 0.361 & Valid & 0.019 & 0.361 & $\mathrm{X}$ \\
\hline 9 & 0.251 & 0.361 & $\mathrm{X}$ & 0.683 & 0.361 & Valid & 0.650 & 0.361 & Valid \\
\hline 10 & 0.557 & 0.361 & Valid & 0.348 & 0.361 & $\mathrm{X}$ & 0.671 & 0.361 & Valid \\
\hline
\end{tabular}

Source: SPSS Output, January 2019.

In Kare, a lot of invalid research instruments, then the researcher repaired the research instrument by removing the wrong question item and then redistribute it to the respondent with output spss version 15.0. as follows:

Table. II. Validity test.

\begin{tabular}{|l|l|l|l|l|l|l|l|l|l|}
\hline \multirow{2}{*}{$\begin{array}{c}\text { No. } \\
P\end{array}$} & \multicolumn{3}{|c|}{ X1 (Fundamental) } & \multicolumn{3}{|c|}{ X2 (technical) } & \multicolumn{3}{|c|}{ Y (Continuity) } \\
\cline { 3 - 6 } & $\mathrm{R}_{\text {Count }}$ & $\mathrm{R}_{\text {Table }}$ & Ket & $\mathrm{R}_{\text {Count }}$ & $\mathrm{R}_{\text {Table }}$ & Ket & $\mathrm{R}_{\text {Count }}$ & $\mathrm{R}_{\text {Table }}$ & Ket \\
\hline 1 & 0.653 & 0.361 & Valid & 0.653 & 0.361 & Valid & 0.740 & 0.361 & Valid \\
\hline 2 & 0.654 & 0.361 & Valid & 0.724 & 0.361 & Valid & 0.485 & 0.361 & Valid \\
\hline 3 & 0.650 & 0.361 & Valid & 0.640 & 0.361 & Valid & 0.794 & 0.361 & Valid \\
\hline 4 & 0.671 & 0.361 & Valid & 0.540 & 0.361 & Valid & 0.683 & 0.361 & Valid \\
\hline 5 & 0.716 & 0.361 & Valid & 0.619 & 0.361 & Valid & 0.723 & 0.361 & Valid \\
\hline 6 & 0.577 & 0.361 & Valid & 0.648 & 0.361 & Valid & 0.671 & 0.361 & Valid \\
\hline
\end{tabular}

Source: SPSS Output, January 2019.

As the results are shown in the table above by using six questions in each Variable indicates that all the price $\mathrm{R}_{\text {count }}>\mathrm{R}_{\text {table }}$ with $\mathrm{N}=30$ (number of 
respondents) at a significant value of $5 \%$ for 0.361 then it can be concluded that all items in the poll of the research are valid so that it can be used as a research instrument (more calculations on Appendix 2).

1. Reliability Test

The reliability test was done using the formula $A L P H A$, and a significant test was done at and $a=0.05$ level. The instrument is said to be reliable if the alpha value is more significant than $\mathrm{R}_{\text {table }}$ (0.361). In the first reliability test, researchers used ten questions in each Variable with the sample (N) of 30 respondents, SPSS output summary version 15.0. Shows the values of alpha $\mathrm{X}_{1}$ (0.152), $\mathrm{X}_{2}$ $(0,263)$, and $Y(0.325)$, indicating that all variables are not reliable because they are under the $\mathrm{R}$ table value (0.361). Therefore, researchers improve the research instrument by using six questions on each Variable with output SPSS version 15.0. as follows:

Table. III, Reliability test.

\begin{tabular}{|l|l|l|l|}
\hline Variable & Alpha & $\mathrm{R}_{\text {Table }}$ & Ket \\
\hline X1 & 0.648 & 0.361 & Reliable \\
\hline X2 & 0.706 & 0.361 & Reliable \\
\hline Y & 0.792 & 0.361 & Reliable \\
\hline
\end{tabular}

Source: SPSS Output, January 2019.

As the results are shown in the table above, all variables indicate above the value of $\mathrm{R}_{\text {table }}(0.361)$, and above the cost of Cronbach's alpha (0.6) Then the poll in this research is reliable so that it can be used as a research instrument.

A. Data Analysis Techniques

1. Test normality

This research will use the One-Sample Kolmogorov-Smirnov test using a significance of 0.05 , test the regularity aims to determine whether the residual value is a normal distribution or not. A good regression model is to have a reasonable residual value. The basis for retrieval decision if the amount is significant $>0.05$, the residual value is normal distribution, and conversely, if the value is $<0.05$, 
then the residual value is not distributed normally. A test of the normality of One-Sample Kolmogorov-Smirnov using SPSS 15.0 for Windows program with the following output:

Table. IV. test normality, One-Sample KolmogorovSmirnov test.

\begin{tabular}{|c|c|c|}
\hline & & $\begin{array}{l}\text { Unstandardi } \\
\text { zed Residual }\end{array}$ \\
\hline $\mathrm{N}$ & & 30 \\
\hline $\begin{array}{l}\text { Normal Parameters } \\
\text { (A, B) }\end{array}$ & Mean & ,0000000 \\
\hline & Std. Deviation & 2.88419256 \\
\hline Most Extreme & Absolute &, 145 \\
\hline & Positive &, 079 \\
\hline & Negative &,- 145 \\
\hline Kolmogorov-Smirno & &, 793 \\
\hline ASHMP. Sig. (2-taile & &, 555 \\
\hline
\end{tabular}

Test distribution is Normal.

b Calculated from data.

Source: SPSS Output, January 2019.

Based on the test output normality above known significance value $0.555>0.05$, it can be concluded that the residual value is normal distribution so that it can be continued with the subsequent testing of data.

2. Multicollinearity Test

The multicollinearity test aims to test whether in a regression model found the correlation between the free variables, and a good regression model should not occur in the correlation between free variables. The Keputusanya retrieval basis is if the value tolerance > 0.10 does not occur multicollinearity, conversely, if the value of understanding $<0.10$ occurs multicollinearity, ON THE Amount of vif if vif $<10.00$ Then there is no multicollinearity, conversely if vif $>10.00$ then occurs multicollinearity. Multicollinearity Test uses the HELP OF spss 15.0 for Windows program with the following Output: 
Table. V. multicollinearity test

\begin{tabular}{|c|c|c|c|c|c|c|c|c|}
\hline \multicolumn{9}{|c|}{ Coeficients } \\
\hline \multirow[b]{2}{*}{ Mode } & & \multicolumn{2}{|c|}{$\begin{array}{l}\text { Unstandardized } \\
\text { Coeficients }\end{array}$} & \multirow{2}{*}{$\begin{array}{l}\text { Standardized } \\
\text { Coefficients }\end{array}$} & \multirow[b]{2}{*}{$t$} & \multirow[b]{2}{*}{ Sig. } & \multicolumn{2}{|c|}{ Collinearity Statistics } \\
\hline & & $B$ & Std. Error & & & & Tolestance & VIF \\
\hline \multirow[t]{3}{*}{1} & (Constant) & 15,068 & 5,024 & & 2,999 &, 006 & & \\
\hline & fundamental & 161 & 281 & 151 & 572 & 572 & 472 & 2,120 \\
\hline & teknikal & 228 & 291 & 207 &, 783 & ,441 & 472 & 2,120 \\
\hline
\end{tabular}

Source: Output SPSS, January 2019.

From the Output above shown, the value of tolerance $0.472>$ 0.10 and the value of Vif $2.120<10.00$ The results both signify the managed data does not occur multicollinearity.

3. Heteroscedasticity Test

One of the requirements that must be met in a functional regression model is that there is no heteroskedasticity symptom, in this study using Heteroskedastisity test scatterplot with a TOOL SPSS 15.0 with the following Output:

Scatterplot

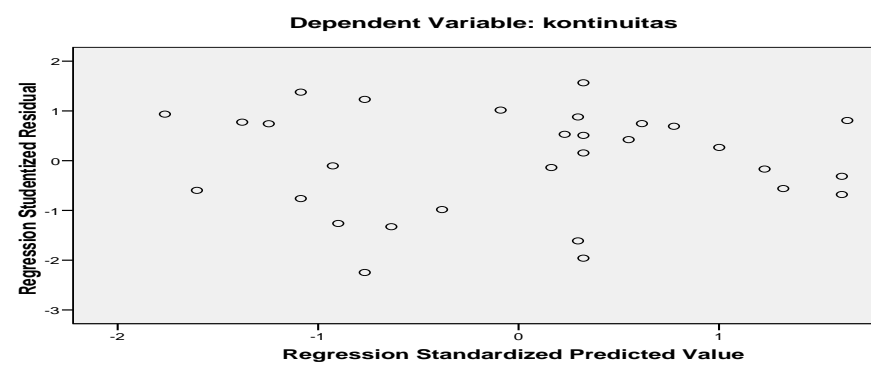

Picture. I. Test heteroskedasticity (Source: Output SPSS, January 2019.

From the picture above, it appears that the point spread does not form a specific pattern/groove, so that it can be inferred does not occur heteroskedasticity or, in other words, occur homoscedasticity. The classic assumption of heteroscedasticity in this model is fulfilled, which is free from heteroscedasticity. This test (scatterplot) is prone to errors in its conclusion. This is because the determination of the above pattern/flow of dots in the image is subjective. It could be that some people say there are no patterns, but others say this is a 
pattern. There is no definite measure when a scatterplot forms a model or not.

B. Influence of knowledge level of fundamental analysis on Continuity of continuities investing in sharia stocks.

In this study, to determine the effect of knowledge level fundamental analysis $\left(\mathrm{X}_{1}\right)$ in an unfavorable to investing Continuity $(\mathrm{Y})$ in sharia stocks using simple linear regression analysis to test the effect of one free Variable to the associated Variable in an unfavorable. The tool used to check it is SPSS 15.0 for Windows with the following Output:

Tabel.VI. Variable SPSS Output $\mathrm{X}_{1}$, Coefficients (a)

\begin{tabular}{|c|c|c|c|c|c|c|}
\hline \multirow[t]{2}{*}{ Model } & & \multicolumn{2}{|c|}{$\begin{array}{l}\text { Unstandardized } \\
\text { Coefficients }\end{array}$} & \multirow{2}{*}{$\begin{array}{c}\begin{array}{c}\text { Standardiz } \\
\text { ed } \\
\text { Coefficien } \\
\text { ts }\end{array} \\
\text { Beta }\end{array}$} & \multirow{2}{*}{$\begin{array}{l}\mathrm{Q} \\
\mathrm{B} \\
\end{array}$} & \multirow{2}{*}{$\begin{array}{l}\text { Sig. } \\
\text { Std. } \\
\text { Error }\end{array}$} \\
\hline & & $\mathrm{B}$ & $\begin{array}{l}\text { Std. } \\
\text { Error }\end{array}$ & & & \\
\hline 1 & $\begin{array}{l}\text { Constant } \\
\text { Fundamental } \\
\text { knowledge } \\
\text { levels }\end{array}$ & $\begin{array}{r}16.904 \\
, 321\end{array}$ & $\begin{array}{r}4.412 \\
, 192\end{array}$ &, 302 & $\begin{array}{l}3.831 \\
1.673\end{array}$ & $\begin{array}{l}, 001 \\
, 105\end{array}$ \\
\hline
\end{tabular}

A Dependent Variable: Continuity

Source: SPSS Output, January 2019.

From the output SPSS above known constant value $(\alpha)$ 16.904, while the value of knowledge level of fundamental analysis $(\beta)$ of 0.321 so that the equation of Regresinya can be written:

$\mathrm{Y}=\alpha+\beta \mathrm{X}$

$=16.904+0,321 \mathrm{x}$

The equation can be translated that the constants of 16.904 mean that the consistent value of the Continuity of investing is 16.904 . Whereas the $\mathrm{X}$ regression coefficient states that each addition of 1value of fundamental knowledge, the value of Continuity of investing increases by 0.321 , the regression coefficient is positive, so it can be said that the direction of the influence of $\mathrm{X}$ variable to $\mathrm{Y}$ is positive. As 
for the significance of the obtained value of $0.105>0.05$, so it can be said that the knowledge level variable fundamental analysis $\left(\mathrm{X}_{1}\right)$ does not affect the variable Continuity of investing (Y). Based on the value $\mathrm{T}$ is known calculated $\mathrm{T}$ value of $1.673<2.048 \mathrm{t}_{\text {table }}$, so count $\leq \mathrm{t}_{\text {table, }}$, or significant $>0.05$, then the Zero hypothesis $(\mathrm{H} 0)$ is received, and the alternative hypothesis (HA) is rejected. The Output indicates that the fundamental analysis knowledge level variable $\left(\mathrm{X}_{1}\right)$ does not affect the investing continuity variable $(\mathrm{Y})$. Calculation of $\mathrm{T}_{\text {table }}$ above obtained in the following way:

$$
\begin{aligned}
\mathrm{T}_{\text {table }} & =(\mathrm{A} / 2: \mathrm{N}-\mathrm{K}-1) \\
& =(0.05 / 2: 30-1-1) \\
& =(0.025: 28) \\
& =2.048
\end{aligned}
$$

Where: $\mathrm{a}=$ significance

$\mathrm{n}=$ number of samples

$\mathrm{k}=$ number of free variables $($ independent Variable $)(\mathrm{X})$

Table. VII. Output SPSS variable $\mathrm{X}_{1}$, Model Summary

\begin{tabular}{|l|r|r|r|r|}
\hline Model & R & R Square & $\begin{array}{l}\text { Adjusted } \\
\text { R Square }\end{array}$ & $\begin{array}{c}\text { Std. An error } \\
\text { of the Estimate }\end{array}$ \\
\hline 1 &, $302(\mathrm{a})$ &, 091 &, 058 & 2.93524 \\
\hline
\end{tabular}

A Predictors: (Constant), a level of fundamental knowledge

Source: SPSS Output, January 2019.

After R count is known for 0.302 , then further to know how large the influence of knowledge level variables fundamental analysis $\left(\mathrm{X}_{1}\right)$ to the variable Continuity of investing (Y) then used coefficient of determination $\mathrm{R}^{2}$ expressed in percentages. The results are as follows: $\mathrm{R}^{2}=(0.302)^{2} \times 100 \%$ $=0.091 \times 100 \%$ $=9.1 \%$

From the results of the above calculations can be concluded the magnitude of the influence of knowledge level variables fundamental analysis $\left(\mathrm{X}_{1}\right)$ to the variable Continuity of investing $(\mathrm{Y})$ is $9.1 \%$, and the rest is $90.9 \%$ influenced by other factors. Another factor in question can be the investor is more interested in reading the chart movements 
shown in the technical analysis of the view and counting the company's financial statements on fundamental analysis.

C. The influence of Knowledge level technical analysis on the basis of Continuity of investing in sharia stocks.

In this study, to determine the influence of technical analysis knowledge level $\left(\mathrm{X}_{2}\right)$ on the Continuity of investing $(\mathrm{Y})$ in sharia stocks using simple linear regression analysis to test the effect of one free Variable on the corresponding Variable. The tool used to check it is SPSS 15.0 for Windows with the following Output:

Table. VIII. Output SPSS variable $\mathrm{X}_{2}$, Coefficients (a)

\begin{tabular}{|c|c|c|c|c|c|c|}
\hline \multirow[t]{2}{*}{ Mode } & & \multicolumn{2}{|c|}{$\begin{array}{c}\text { Unstandardized } \\
\text { Coefficients }\end{array}$} & \multirow{2}{*}{$\begin{array}{c}\text { Standardize } \\
\mathrm{d} \\
\text { Coefficients } \\
\text { Beta } \\
\end{array}$} & \multirow{2}{*}{$\begin{array}{l}\mathrm{Q} \\
\mathrm{B}\end{array}$} & \multirow{2}{*}{$\begin{array}{c}\text { Sig. } \\
\text { Std. Error }\end{array}$} \\
\hline & & B & $\begin{array}{l}\text { Std. } \\
\text { Error }\end{array}$ & & & \\
\hline 1 & $\begin{array}{l}\text { Constant } \\
\text { Knowledge } \\
\text { Level } \\
\text { technical } \\
\text { Anolysis }\end{array}$ & $\begin{array}{r}15.825 \\
, 349\end{array}$ & 4.788 &, 317 & 3.305 &, 003 \\
\hline
\end{tabular}

A Dependent Variable: Continuity

Source: SPSS Output, January 2019.

From the output SPSS above known constant value $(\alpha)$ 15.825, while the knowledge level of technical analysis $(\beta)$ value of 0.349 so that the equation Regresinya can be written:

$\mathrm{Y}=\alpha+\beta \mathrm{X}$ $=15.825+0,349 \mathrm{x}$

The equation can be translated that the constants of 15.825 mean that the consistent value of the Continuity of investing is 15.825 . Whereas the $\mathrm{X}$ regression coefficient states that each addition of the 1 value of the technical analysis knowledge, the value of Continuity of investing increased by 0.349 , the regression coefficient is positive, so it can be said that the direction of the effect of $\mathrm{X}$ variable on $\mathrm{Y}$ is positive. As for the significance of the obtained value of $0.088>0.05$, so it can 
be said that the knowledge level variable technical analysis $\left(\mathrm{X}_{2}\right)$ does not affect the variable Continuity of investing. Based on the value $\mathrm{T}$ is known calculated $\mathrm{T}$ value of $1.767<2.048 \mathrm{t}_{\text {table }}$ so that $\mathrm{T}_{\text {count }}<\mathrm{T}_{\text {table }}$, or significant $>0.05$, then the Zero hypothesis $(\mathrm{H} 0)$ was received and an alternate hypothesis (Ha) was rejected. The Output indicates that the knowledge level variable of technical analysis $\left(\mathrm{X}_{2}\right)$ does not affect the variable continuity of investing (Y). Calculation of $\mathrm{T}_{\text {table }}$ above obtained in the following way:

$\mathrm{T}_{\text {table }}=(\mathrm{A} / 2: \mathrm{N}-\mathrm{K}-1)$

$=(0.05 / 2: 30-1-1)$

$=(0.025: 28)$

$=2.048$

Where: $\mathrm{a}=$ significance

$\mathrm{n}=$ number of samples

$\mathrm{k}=$ number of independent variables $(\mathrm{X})$

Table. IX. Output SPSS variable $\mathrm{X}_{2}$ Model Summary

\begin{tabular}{|l|r|r|r|c|}
\hline $\begin{array}{l}\text { Mode } \\
1\end{array}$ & $\mathrm{R}$ & R Square & $\begin{array}{c}\text { Adjusted } \\
\text { R Square }\end{array}$ & $\begin{array}{c}\text { Std. An } \\
\text { error of the } \\
\text { Estimate }\end{array}$ \\
\hline 1 &, 317 (a) &, 100 &, 068 & 2.92005 \\
\hline
\end{tabular}

A Predictors: (Constant), a level of technical analysis knowledge

Source: SPSS Output, January 2019.

After $\mathrm{R}$ count is known for 0.317 than to know how large the influence of knowledge level variables of technical analysis $\left(\mathrm{X}_{2}\right)$ against the continuity variable Invest (Y) then used coefficient of determination $\mathrm{R}^{2}$ expressed in percentages. The results are as follows:

$\mathrm{R}^{2}=(0.317)^{2} \times 100 \%$

$=0.1004 \times 100 \%$

$=10.04 \%$

From the calculations above, there is a variable influence on the knowledge level of technical analysis $\left(\mathrm{X}_{2}\right)$ to the variable Continuity of investing (Y) of $10.04 \%$, and the rest of which other factors influence $89.96 \%$. The ratio shown in the coefficient of determination is only $10.4 \%$ investor Investment gallery Iain Kerinci has an interest in Technical analysis $\left(\mathrm{x}_{2}\right)$ This figure is still large if compared with 
interest in the fundamental analysis $\left(\mathrm{x}_{1}\right)$ that is $9.1 \%$ but doing so does not make technical analysis $\left(\mathrm{x}_{2}\right)$ Raises the interest of investors to invest in Sharia stocks, proven $89.96 \%$ of investors are not interested or more interested in other factors such as playing social media than in having to monitor the movement of stocks on the Technical Analysis chart $\left(\mathrm{X}_{2}\right)$.

D. Influence of knowledge level of fundamental and technical analysis simultaneously on Continuity of investing in sharia stocks.

To determine the impact of the knowledge level of structural analysis $\left(\mathrm{x}_{1}\right)$ and technical $\left(\mathrm{x}_{2}\right)$ simultaneously against the Continuity of investing (Y) in the Sharia stock regression analysis used is a double linear regression analysis to test the effect of a free variable on simultaneously associated variables (together). The tool used to test it is SPSS 15.0 for Windows with the following Output:

Table. X. Variable SPSS Output X1 and X2 (simultaneous), Coefficients (a)

\begin{tabular}{|ll|r|r|r|r|r|}
\hline \begin{tabular}{|} 
Mo \\
del
\end{tabular} & \multicolumn{2}{|c|}{$\begin{array}{c}\text { Unstandardized } \\
\text { Coefficients }\end{array}$} & $\begin{array}{c}\text { Standardized } \\
\text { Coefficients }\end{array}$ & Q & Sig. \\
\hline & \multicolumn{1}{|c|}{ B } & \multicolumn{1}{|c|}{$\begin{array}{c}\text { Std. } \\
\text { Error }\end{array}$} & Beta & B & $\begin{array}{c}\text { Std. } \\
\text { Error }\end{array}$ \\
\hline 1 & Constant & $\begin{array}{r}15.06 \\
8\end{array}$ & 5.024 & & 2.9 &, 006 \\
& $\begin{array}{l}\text { fundamental_knowl } \\
\text { edge_analysis level } \\
\text { technical_analysis_ } \\
\text { value_rate }\end{array}$ &, 161 &, 281 &, 151 & 572 &, 572 \\
&, 228 &, 291 &, 207 & 783 &, 441 \\
\hline
\end{tabular}

Source: Output SPSS, January 2019.

A Variable Dependent: kontinuitas_berinvestasi

From the SPSS output is known constant value $(\alpha)$ 15.068, while the fundamental Analysis Knowledge Level value ( $\beta 1$ ) 0.161 and technical $(\beta 2)$ amounted to 0.228 so that the Regresinya equation can be written:

$\mathrm{Y}=\alpha+\beta 1 \mathrm{X} 1+\beta 2 \mathrm{X} 2$

$=15.068+0,161 \times 1+0,228 \times 2$ 
The equation can be translated that the constants of 15.068 mean that the consistent value of the continually investing is 15.068 . Whereas the $\mathrm{X}$ regression coefficient states that each addition of 1 fundamental analysis knowledge Value $\left(\mathrm{X}_{1}\right)$, then the value of Continuity of investing increased by 0.161 . And every addition of 1 knowledge analysis technical value $\left(\mathrm{X}_{2}\right)$, then the value of Continuity of investing increased by 0.228 , the regression coefficient is a positive value, so it can be said that the direction of the influence of variables $x_{1}$ and $x_{2}$ to $\mathrm{Y}$ is positive.

Table. XI SPSS Output variable X1 and X2 (simultaneous), ANOVA (b)

\begin{tabular}{|c|c|c|c|c|c|c|}
\hline $\begin{array}{l}\text { Moc } \\
\text { el }\end{array}$ & & $\begin{array}{l}\text { Sum of } \\
\text { Squares }\end{array}$ & Df & $\begin{array}{l}\text { Mean } \\
\text { Square }\end{array}$ & F & Sig. \\
\hline \multirow[t]{3}{*}{1} & Regressio & 29.481 & 2 & \multirow{3}{*}{$\begin{array}{r}14.740 \\
8.737\end{array}$} & \multirow[t]{3}{*}{1.687} & \multirow[t]{3}{*}{,204 (a) } \\
\hline & Residual & 235.886 & 27 & & & \\
\hline & Total & 265.367 & 29 & & & \\
\hline
\end{tabular}

A Predictors: (Constant), tingkat_pengetahuan_analisis_teknikal, tingkat_pengetahuan_analisis_fundamental b Dependent Variables: kontinuitas_berinvestasi Source: SPSS Output, January 2019.

As for the significance of the obtained value of $0.204>0.05$, so it can be said that the knowledge level variables of fundamental analysis $\left(\mathrm{X}_{1}\right)$ and technical $\left(\mathrm{x}_{2}\right)$ simultaneously (together) do not affect the variable Continuity of investing (Y). Based on the value $\mathrm{F}$ is known as the count $F$ value of $1.687<3.374 \mathrm{f}_{\text {table }}$ so that the $F_{\text {count }}<\mathrm{f}_{\text {table, }}$, or significant $>0.05$, then the Zero hypothesis $(\mathrm{H} 0)$ was received and an alternate hypothesis (Ha) was rejected. The Output indicates that the knowledge level variables of the fundamental $\left(\mathrm{x}_{1}\right)$ and technical $\left(\mathrm{x}_{2}\right)$ analyses simultaneously (together) do not affect the variable continuities of investing (Y). Calculation of $\mathrm{F}_{\text {table }}$ above obtained in the following way:

$\mathrm{F}_{\text {table }}=(\mathrm{k}: \mathrm{n}-\mathrm{K})$

$=(2: 30-2)$ 
$=(2: 28)$

$=3.34$

Where: $\mathrm{a}=$ significance

$\mathrm{n}=$ Amount sample

$\mathrm{k}=$ Amount Independent Variabel (independent variable) (X)

Table. XII. Variable Output SPSS X1 and X2

(simultaneous), Model Summary

\begin{tabular}{|l|r|r|r|c|}
\hline $\begin{array}{l}\text { Mode } \\
1\end{array}$ & $\mathrm{R}$ & R Square & $\begin{array}{c}\text { Adjusted } \\
\text { R Square }\end{array}$ & $\begin{array}{c}\text { Std. The } \\
\text { error of the } \\
\text { Estimate }\end{array}$ \\
\hline 1 &, 333 (a) &, 111 &, 045 & 2.95576 \\
\hline
\end{tabular}

A Predictors: (Constant), tingkat_pengetahuan_analisis_teknikal, tingkat_pengetahuan_analisis_fundamental Source: SPSS Output, January 2019.

After $\mathrm{R}$ count is known for 0.333 , then the next to know how much of the influence of knowledge level fundamental analysis $\left(\mathrm{x}_{1}\right)$ and technical $\left(\mathrm{x}_{2}\right)$ simultaneously (together) against the Continuity of investing ( $\mathrm{Y}$ ) used a coefficient of determination $\mathrm{R}^{2}$ expressed in percentages. The results are as follows:

$\mathrm{R}^{2}=(0.333)^{2} \times 100 \%$

$=0.1108 \times 100 \%$

$=11.08 \%$

From the results of the above calculations can be concluded the magnitude of influence of knowledge level of fundamental analysis $\left(\mathrm{x}_{1}\right)$ and technical $\left(\mathrm{x}_{2}\right)$ simultaneously (together) against investment continuity (Y) of $11.08 \%$ and the rest of which is $88.92 \%$ influenced by other factors.

Investors of IAIN Kerinci Islamic Investment gallery are more likely to buy shares suggested by the Broker (FAC Sekuritas) and then see the price movement of its shares on the chart without seeing the prospects of the stock, $88.92 \%$ of investors have no interest in the analysis of sharia stocks because they are necessarily not interested in the world of stocks, investors who $95 \%$ are students more likely to be involved in Generally, investors have a share account because they require the campus as one of the requirements to be a student FEBI 
IAIN Kerinci. While there are $11.08 \%$ of investors, have an interest in sharia stocks, the figure is the investors who are members of the Capital Market Study Group (KSPM) IAIN Kerinci is a student who has a responsibility and active role in the management of Sharia investment gallery BEI IAIN Kerinci.

\section{CONCLUSION}

The validity of research researchers do as follows:

1. In a partial $\left(\mathrm{X}_{1}\right)$ fundamental Analysis level(s) test the resultant variable Continuity investment (Y) output is for the significance of the acquired value of $0.105>0.05$, and the $\mathrm{T}$ value is known as the calculated $\mathrm{T}$ value of $1.673<2.048 \mathrm{t}_{\text {table }}$ so $\mathrm{t}_{\text {count }} \leq \mathrm{t}_{\text {table, }}$, or significant $>0.05$, then the Zero hypothesis (H0) is received and the alternative hypothesis (HA) is rejected. The Output indicates that the fundamental analysis knowledge level variable $\left(\mathrm{X}_{1}\right)$ does not affect the investing continuity variable $(\mathrm{Y})$.

2. While the influence of Knowledge level technical analysis $\left(X_{2}\right)$ is partially against Continuity (Y) invests in sharia stocks for the significance of the acquired value of $0.088>0.05$, and the $\mathrm{T}$ value is known calculated $t$ value of $1.767<2.048 t_{\text {table }}$ so that $T_{\text {count }}<\mathrm{T}_{\text {table, }}$, or significant $>0.05$, then the Zero hypothesis $(\mathrm{H} 0)$ was received and an alternate hypothesis (Ha) was rejected. This indicates that the knowledge level variable of technical analysis $\left(\mathrm{X}_{2}\right)$ has no effect on the variable continuities of investing (Y).

3. The Output of multiple linear regression analyses to determine the simultaneous influence of the fundamental $\left(\mathrm{x}_{1}\right)$ and technical $\left(\mathrm{x}_{2}\right)$ analytical levels of the (s), the (Y)) Investing in sharia stocks for the significance of the value obtained at $0.204>0.05$, and the $\mathrm{F}$ value of $\mathrm{T}$ calculated $F$ value of $1.687<><3.340 .05$, then a zero hypothesis (H0) was received, and an alternate hypothesis ( $\mathrm{Ha}$ ) was rejected. The Output indicates that the knowledge level variables of the fundamental $\left(\mathrm{x}_{1}\right)$ and 
technical $\left(\mathrm{x}_{2}\right)$ analyses simultaneously (together) do not affect the variable continuities of investing $(\mathrm{Y})$.

\section{BIBLIOGRAPHY}

Abdul Aziz, A. A. (2008). Islamic economics, micro-\& Macro Analysis. Yogyakarta: Graha Ilmu.

Ahmad Yusron, A. Y. (2012). The influence of guidance Career And parenting parenting against student self-reliance in choosing Career In class Xi Department of electrical power installation Engineering Smk Negeri 1 Sedayu. Yogyakarta: UNY Press.

Astutik, E. D., Surachman, S., \& Djazuli, A. (2015). The effect of fundamental and technical variables on stock price (Study on manufacturing companies listed in Indonesia Stock Exchange). Journal of Economics, Business, and Accountancy | Ventura, 17(3), 345. https://doi.org/10.14414/jebav.v17i3.356

Kurniawan Albert, K. A. (2014). Method Research for economics and business. Bandung: the Most.

M. Nur Rianto Al Arif, M. N. R. A. A. (2012). Sharia financial institutions,. Bandung: CV. Bandung.

Melvilius Welby Cardinal, M. W. C. (2015). Influence Fundamental variables and effects Technical On the stock price of registered coal mining sector companies Bei Period 2012-2014. Jakarta: Rausan Press.

Prabhata, A. (2012). Efektifitas Penggunaan Analisis Teknikal Stochastic Oscillator dan Moving Average Convergence-Divergence (MACD) pada Perdagangan SahamSaham Jakarta Islamic Index (JII) di Bursa Efek Indonesia. Sinergi, 13(1), 1-14. https://doi.org/10.20885/sinergi.vol13.iss1.art1

Sakinah. (2014). Investing in Islam, Iqtishadia (2nd ed., Vol. 5). Sei Penuh: IAIN Kerinci.

subana, subana. (2005). Fundamentals of scientific research. Bandung: CV The Faitfhul Library.

Suharsimi Arikunto, S. A. (2002). Research procedure of a practice approach. Jakarta: $\mathrm{Pt}$ Rineka Copyright.

Tashih al-Qur'an, T. al-Qur'an. (2006). Al-Quran, The Library, (1st ed., Vol. 1). Jakarta: Depertemen Religion of the Republic of Indonesia. 